Kathi Mujynya-Ludunge

Hema Viswambharan

Robert Driscoll

Xiu-Fen Ming

Ludwig K. von Segesser

Lukas Kappenberger

Zhihong Yang

Giuseppe Vassalli

\section{Endothelial nitric oxide synthase gene transfer restores endothelium-dependent relaxations and attenuates lesion formation in carotid arteries in apolipoprotein E-deficient mice}

Received: 19 April 2004

Returned for revision: 14 May 2004

Revision received: 22 September 2004

Accepted: 20 October 2004

Published online: 24 November 2004

K. Mijynya-Ludunge $\cdot$ R. Driscoll

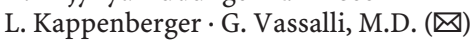

Division of Cardiology,

University of Lausanne

Faculty of Biology and Medicine

CHUV-BH10

1011 Lausanne, Switzerland

Tel.: +41-21/314-0076

Fax: +41-21/314-0012

E-Mail: giuseppe.vassalli@chuv.hospvd.ch

K. Mujynya-Ludunge $\cdot \mathrm{G}$. Vassalli

Institute of Microbiology,

University of Lausanne

Faculty of Biology and Medicine

Lausanne, Switzerland

H. Viswambharan $\cdot$ X.-F. Ming $\cdot$ Zh. Yang

Institute of Physiology

University of Fribourg

Fribourg, Switzerland

L. K. von Segesser

Division of Cardiovascular Surgery,

University of Lausanne

Faculty of Biology and Medicine

Lausanne, Switzerland
Abstract Nitric oxide (NO) and monocyte chemoattractant protein-1 (MCP-1) exert partly opposing effects in vascular biology. NO plays pleiotropic vasoprotective roles including vasodilation and inhibition of platelet aggregation, smooth muscle cell proliferation, and endothelial monocyte adhesion, the last effect being mediated by MCP-1 downregulation. Early stages of arteriosclerosis are associated with reduced NO bioactivity and enhanced MCP-1 expression. We have evaluated adenovirus-mediated gene transfer of human endothelial NO synthase (eNOS) and of a $\mathrm{N}$-terminal deletion (8ND) mutant of the MCP-1 gene that acts as a MCP-1 inhibitor in arteriosclerosis-prone, apolipoprotein E-deficient $\left(\mathrm{ApoE}^{-/}\right)$mice. Endotheliumdependent relaxations were impaired in carotid arteries instilled with a noncoding adenoviral vector but were restored by eNOS gene transfer $(p<$ 0.01 ). A perivascular collar was placed around the common carotid artery to accelerate lesion formation. eNOS gene transfer reduced lesion surface areas, intima/media ratios, and macrophage contents in the media at 5-week followup $(p<0.05)$. In contrast, 8ND-MCP-1 gene transfer did not prevent lesion formation. In conclusion, eNOS gene transfer restores endothelium-dependent vasodilation and inhibits lesion formation in $\mathrm{ApoE}^{-/-}$mouse carotids. Further studies are needed to assess whether vasoprotection is maintained at later disease stages and to evaluate the long-term efficacy of eNOS gene therapy for primary arteriosclerosis.

Key words NO synthase - MCP-1 - arteriosclerosis - endothelium apolipoprotein-E - mouse - gene therapy

\section{Introduction}

Endothelial nitric oxide (NO) synthase (eNOS) constitutively produces $\mathrm{NO}$, a potent vasodilator that mediates pleiotropic vasoprotective effects such as inhibition of endothelial leukocyte adhesion, suppression of platelet aggregation, and negative regulation of vascular smooth muscle cell (VSMC) proliferation [10, 31, 51]. Endothe- lium-dependent vasodilation is impaired in hypercholesterolemic animals and humans, suggesting that NO bioactivity is decreased at early stages of vascular disease $[12,43]$. Administration of the NO precursor L-arginine has been shown to correct endothelial dysfunction in hypercholesterolemic patients [11]. Chronic dietary administration of L-arginine induces regression of early intimal lesions and attenuates progression of atherosclerotic plaques in hypercholesterolemic mice and rabbits 
$[1,3]$. Conversely, chronic administration of NO antagonists promotes lesion formation in hypercholesterolemic rabbits [7]. There is experimental and clinical evidence to show that eNOS protein levels are decreased in the endothelium overlying severe atherosclerotic lesions in arteries $[13,27,47]$ and diseased bypass grafts [5]. However, reduced NO bioactivity has also been described in association with normal or even increased eNOS protein levels $[2,12]$. These findings illustrate the complexity of the mechanisms underlying the observed decrease in NO bioactivity in diseased arteries.

Mice deficient in the apolipoprotein E gene $\left(\mathrm{ApoE}^{-/}\right)$ provide a useful model for studying atherosclerosis in that complex arterial lesions in this model mimic those observed in humans [33]. Lesion formation is further accelerated in ApoE/eNOS double-knockout mice compared with $\mathrm{ApoE}^{-/-}$mice [20]. Conversely, reduced lesion formation in a model of vascular remodeling [19], as well as hypotension and reduced $\mathrm{NO}$-elicited vasorelaxation [28] have been reported in ApoE $\mathrm{E}^{-/} / \mathrm{eNOS}$ transgenic mice that overexpress eNOS in the vascular endothelium, as compared with $\mathrm{ApoE}^{-/-}$mice. In contrast, a recent study [30] showed accelerated lesion formation in $\mathrm{ApoE}^{-/-1}$ eNOS transgenic mice, which was reversed by supplementation with tetrahydrobiopterin, an important $\mathrm{NO}$ cofactor.

Previous studies have demonstrated that eNOS gene transfer improves vasodilation in endothelial dysfunction, while reducing neointimal hyperplasia in mechanically injured arteries [9]. In vitro eNOS gene transfer improved vasorelaxation in canine coronary arteries during hypoxia [6] and carotid arteries from diabetic rabbits [23] and $\mathrm{eNOS}^{-1-}$ mice [21]. In vivo eNOS gene transfer attenuated acute hypoxic pulmonary vasoconstriction in rats [16] and improved carotid artery dilatation in hypercholesterolemic rabbits $[8,35]$. Furthermore, eNOS gene transfer inhibited hyperplastic neointima formation in balloon-injured rat carotid arteries $[9,17]$, pig coronary arteries [40], and atherosclerotic $\mathrm{ApoE}^{-/-}$mouse carotid arteries [45]. However, eNOS gene transfer has not been investigated in models of primary arteriosclerosis that do not rely on mechanical endovascular injury to promote lesion formation.

NO and monocyte chemoattractant protein-1 (MCP1) play partly opposing roles in vascular biology. MCP-1 is expressed in endothelial cells, VSMC, monocytes, and adipocytes in response to inflammatory stimuli such as TNF- $\alpha$, IL-1 $\beta$, and IL-4 [36]. MCP-1 expression is detectable in aortas from hypercholesterolemic, but not from normal, rabbits [48]. Downregulation of MCP-1 expression is a mechanism by which NO inhibits monocyte adhesion to the endothelium [26, 37, 38, 49]. MCP-1 expressed by human aortic endothelial cells and VSMC in response to minimally modified low-density lipoprotein (LDL) cholesterol accounts for virtually all of the monocyte chemotactic activity under these conditions
[32]. Mice deficient in MCP-1 show abnormal monocyte recruitment and cytokine expression [22]. Mice deficient in the $\mathrm{C}-\mathrm{C}$ chemokine receptor-2 (CCR2), the main receptor for MCP-1, display reduced arterial lesion formation with less macrophage infiltrates [4]. These findings establish a central role for MCP-1 in atherogenesis, while providing a rationale for anti-MCP-1 therapy. Among MCP- 1 inhibitors, $N$-terminally truncated MCP1 peptides have been shown to block MCP-1-mediated monocyte chemotaxis with high efficacy both in vitro and in vivo $[14,50]$. Gene transfer of the $7 \mathrm{~N}$-terminal deletion (ND) mutant of the human MCP-1 gene inhibited post-angioplasty neointima formation in rat and monkey arteries [39]. Injection of the same gene construct into remote muscles attenuated aortic lesion formation and progression in $\mathrm{ApoE}^{-/-}$mice $[15,25]$. However, arterial gene transfer of a MCP-1 inhibitor has not been studied in the absence of angioplasty injury. Therefore, we have evaluated arterial eNOS and anti-MCP-1 gene transfer-based approaches in carotid arteries in $\mathrm{ApoE}^{-/-}$mice.

\section{Methods}

\section{Adenoviral vectors}

The expression plasmid encoding human eNOS (pUC18eNOS) was kindly provided by Daniel Hayoz (Lausanne, Switzerland). Generation of recombinant adenovirus expressing Xpress-tagged human eNOS driven by the cytomegalovirus (CMV) promoter was carried out by homologous recombination between co-transformed virusmid and the corresponding adenoviral transfer plasmid in E. coli, as described [24]. The eNOS cDNA was first subcloned into the pcDNA3.1/His-A vector (Invitrogen) allowing the insertion of the transgene into the $\mathrm{E} 1$ region of a cloned $\Delta \mathrm{E} 1, \Delta \mathrm{E} 3$ adenoviral backbone (vmAdcDNA3) bearing an empty expression cassette homologous to the one of pcDNA3.1/His. The transfer plasmid pcDNA3.1/His-eNOS was digested with SalI, and co-transformed with SwaI-linearized vmAdcDNA3 into BJ5183. Recombinants were screened by colony PCR followed by re-transformation of positive clones into strain HB101, allowing for higher plasmid yields. Recombinant virusmids were digested with $\mathrm{PacI}$ and transfected into HER911 cells to generate recombinant adenovirus AdCMV-eNOS. The cDNA sequence of human MCP-1 was kindly provided by Etienne Régulier (Lausanne, Switzerland). The cDNA sequence corresponding to the $8 \mathrm{ND}$ mutant of the MCP-1 gene encoding a truncated MCP-1 peptide lacking amino acid residues 1-8 was obtained by PCR using site-directed deletion by overlap extension. 8ND-MCP-1 cDNA was sequenced and sub- 
cloned into the pcDNA3.1/A vector. Recombinant adenovirus Ad.CMV-8ND-MCP-1 was generated by homologous recombination with the co-transfected, ClaIdigested large fragment of a $\Delta \mathrm{E} 1, \Delta \mathrm{E} 3$-adenoviral vector genome in human 293 cells. Recombinant adenovirus Ad-BHG3 containing no transgene (Ad-Null) was used as a control. Recombinant adenovirus Ad.CMV-EGFP containing an enhanced green fluorescent protein (EGFP) expression cassette [42] was used to assess arterial gene transfer efficiency. Concentrated virus stocks were prepared using two $\mathrm{CsCl}_{2}$ ultracentrifugation gradients and stored in storage buffer $(10 \mathrm{mmol} / \mathrm{L}$ Tris- $\mathrm{HCl}, \mathrm{pH} 7.4,1$ $\mathrm{mmol} / \mathrm{L} \mathrm{MgCl}_{2}, 10 \%$ glycerol). Virus titers of Ad.CMVeNOS, Ad.CMV-8ND-MCP-1, Ad-Null, and Ad.CMVEGFP stock solutions determined by plaque titration assay were $2 \times 10^{11}, 6 \times 10^{10}, 1 \times 10^{11}$, and $3 \times 10^{11}$ plaque forming units (PFU)/ml, respectively (virus particles/ PFU ratios $\approx 5-30$ ).

\section{Mice}

Animal work was approved by the local regulatory authority and was performed in compliance with guidelines on animal experimentation at our institution. Male C57BL/6 J ApoE-- mice [33] were purchased from Transgenic Alliance (France) and maintained on a 12-hour light-dark cycle. They were fed standard chow until 1820 weeks of age when they underwent gene transfer and were placed on a Western-type diet (Harlan TD88137, $21.2 \%$ total fat, $0.2 \%$ cholesterol) for 2 weeks, followed by standard chow for 3 weeks.

\section{In vivo gene transfer}

Gene transfer into mouse carotid arteries was performed essentially as described [42]. Briefly, mice ( $n=7$ /group) were anesthetized by i.p. ketamine/xylazine. The left carotid artery was surgically exposed, and a segment of the common carotid artery was isolated by placement of a vascular clamp on the proximal part of the artery, while the internal carotid artery was ligated with a polypropylene monofilament suture (7-0 Surgilene; Geck and Davis) immediately after the bifurcation. The external carotid artery was ligated $2-3 \mathrm{~mm}$ distally of the bifurcation. A silicone catheter (.O12" I.D., .025 O.D.; Helix Medical) was introduced into the common carotid artery through an arteriotomy of the external carotid artery, and blood was flushed out the common carotid artery by injecting 0.3-0.4 ml M-199 medium (Gibco BRL). Virus vector stocks were thawed and diluted with M-199 medium supplemented with $1 \mathrm{mg} / \mathrm{ml}$ purified mouse albumin fraction $\mathrm{V}$ (Sigma) to the final concentration of $2 \times 10^{10} \mathrm{PFU} / \mathrm{ml}$. This concentration was chosen based on our previous dose-response study [42]. A second catheter was reintroduced, and vector containing medium was instilled into the isolated common carotid segment. The duration of the virus incubation period was 20 minutes. Vector containing medium was then withdrawn and blood flow was re-established through the common and internal carotid arteries. To accelerate lesion formation, a perivascular collar prepared from Silastic tubing (inside diameter $\approx 0.3 \mathrm{~mm}$; length $\approx 3 \mathrm{~mm}$ ) was placed around the central portion of the left common carotid artery, as described by von der Thüsen et al. [44]. The collar results in a modest reduction in vessel lumen $(\approx 30 \%)$ that does not limit blood flow but causes flow disturbances that accelerate lesion formation within 3-6 weeks in $\mathrm{ApoE}^{-/-}$mice fed a Western-type diet $[44,45]$. The axial edges of the collar were approximated by placement of 3 circumferential silk ties. Subsequently, the cervical wound was closed.

\section{Detection of human eNOS and 8ND-MCP-1}

Human eNOS protein in $\mathrm{ApoE}^{-/-}$carotid arteries instilled in vivo with Ad.CMV-eNOS or Ad-Null ( $\mathrm{n}=3$ each) was detected by Western blotting. Briefly, crude protein extracts were obtained by homogenizing snap-frozen arteries in protein extraction buffer, as described [24]. Protein concentrations were measured by the Bradford method. Protein samples $(30 \mu \mathrm{g})$ were subjected to SDSPAGE and transferred to a PVDF membrane (Millipore). Mouse anti-eNOS mAb (Transduction Lab.) and antimouse alkaline phosphatase-conjugated secondary $\mathrm{Ab}$ were used and visualized with Western Blue Stabilized Substrate (Uptima). Signals were quantified densitometrically by the NIH Image-1.62 software. NOS levels were normalized against total actin levels. Human 8ND-MCP1 protein was measured by a commercially available human MCP-1 ELISA kit (Biosource) that does not react with endogenous mouse MCP-1 [15].

\section{Vascular reactivity studies}

Vessel rings ( $\approx 3 \mathrm{~mm}$ in length) with intact endothelium were cut from carotid arteries isolated from $\mathrm{ApoE}^{-/-}$mice (18-20 weeks of age) fed a Western-type diet at day 5 after in vivo gene transfer with Ad.CMV-eNOS or Ad-Null $(\mathrm{n}=4$ each). They were suspended in a modified KrebsRinger bicarbonate solution (in $\mathrm{mmol} / \mathrm{L}, \mathrm{NaCl} 118, \mathrm{KCl}$ 4.7, $\mathrm{CaCl}_{2} 2.5, \mathrm{MgSO}_{4} 1.2, \mathrm{KH}_{2} \mathrm{PO}_{4} 1.2, \mathrm{NaHCO}_{3} 25$, edetate calcium disodium 0.026 , and glucose 11.1) in a MultiMyograph System (Model 610M, Danish Myo Technology A/S, Denmark). The carotid rings were contracted with norepinephrine $(0.3 \mu \mathrm{mol} / \mathrm{L})$. Endotheliumdependent and -independent relaxations were examined with acetylcholine and sodium nitroprusside, respectively. 


\section{Tissue harvesting and preparation}

For histological analysis of arterial lesions, mice were sacrificed by a lethal pentobarbital dose at 5 weeks after gene transfer. In situ perfusion-fixation through the left cardiac ventricle was performed by PBS instillation for 5 minutes, followed by constant-pressure $(80 \mathrm{mmHg})$ infusion of $4 \%$ neutral buffered formalin for 10 minutes. Subsequently, the perivascular collar was removed and the carotid artery was harvested and kept in $4 \%$ formalin for 24 hours. The specimens were embedded in OCT compound (Tissue-Tek; Sakura Finetek) and snapfrozen in liquid nitrogen. Five series of carotid cross-sections ( $\mathrm{n}=10$ each) at $7 \mu \mathrm{m}$ of thickness were cut at $\sim 0.3$ $\mathrm{mm}$ step intervals throughout the vessel segment subjected to gene transfer.

\section{Histological and immunohistochemical analysis}

Two series of arterial cross-sections were stained with hematoxylin and eosin (H\&E) and elastic/van Gieson for optimal visualization of the internal elastic lamina. Immunostaining for macrophages was performed on additional sections using anti-mouse Mac-2 mAb (Cedarlane) and a biotin-conjugated rabbit-anti-rat IgG secondary $\mathrm{Ab}$, followed by StreptABComplex/HRP and $\mathrm{DAB} / \mathrm{H}_{2} \mathrm{O}_{2}$ (Dako). Sections were counter-stained with eosin. Images were acquired using a Hyper-HAD-Axioscop microscope and an Axiocam-MRcD camera (Zeiss). Morphometric analysis of intima and media surface areas was performed by the NIH Image-1.62 software. The intima surface area was calculated by subtracting the patent lumen area from the area encompassed by the internal elastic lamina. The media surface area was measured as the area between the external and the internal



Fig. 1 Fluorescence photomicrograph of a mouse carotid artery 3 days after in vivo gene transfer with Ad.CMV-EGFP. Fluorescent, EGFP expressing endothelial cells lining the vessel lumen are shown (arrows). Three layers of elastic fibers in the media exhibit auto-fluorescence (200x original magnification) elastic lamina. The intima/media ratio was calculated by dividing the intima surface area by the media surface area. Macrophages in arterial lesions and in the media were counted on Mac-2-immunostained sections, and normalized by the respective surface areas.

\section{Measurement of plasma lipid levels}

Serum total cholesterol and HDL-cholesterol (HDL-C) were measured using commercially available kits (Cholesterol RTU and HDL-Cholesterol Direct, BioMerieux).

\section{Statistical analysis}

Statistical analysis of arterial relaxations was performed by one-way ANOVA with Bonferroni post-test. Arterial intima and media surface areas, intima/media ratios, and macrophage contents are median values (range); they were compared between either the eNOS or the 8ND-MCP-1 gene transfer group and the Ad-Null group by the Mann-Whitney $U$ test. Plasma lipid levels are mean values + SEM; they were compared between groups by ANOVA. A level of $p<0.05$ was considered to be significant.

\section{Results}

\section{Gene transfer efficiency}

The efficiency of arterial gene transfer was assessed using an EGFP expressing vector. Arteries $(n=3)$ were harvested at 3 days after gene transfer, and EGFP expressing cells were visualized on arterial sections under a fluorescence microscope. Approximately $10 \%$ of the endothelial cells lining the vessel lumen, but virtually no VSMC in the media, expressed EGFP at a histologically detectable level (Fig. 1). No fluorescent cells were observed in arteries instilled with Ad-Null.

\section{eNOS and 8ND-MCP-1 expression}

Western blot analysis for eNOS protein was performed on tissue extracts from mouse carotids harvested at 5 days after in vivo gene transfer with Ad.CMV-eNOS or Ad-Null. The eNOS signal in eNOS gene-transduced arteries was increased 2.3-fold compared with endogenous eNOS expression in arteries instilled with Ad-Null (Fig. 2). A human MCP-1 ELISA that recognizes human 8ND-MCP-1 but not mouse MCP-1 (15) detected 360 $\mathrm{pg} / \mathrm{gram}$ of tissue after $8 \mathrm{ND}-\mathrm{MCP}-1$ gene transfer (AdNull, $<30 \mathrm{pg} /$ gram of tissue). 


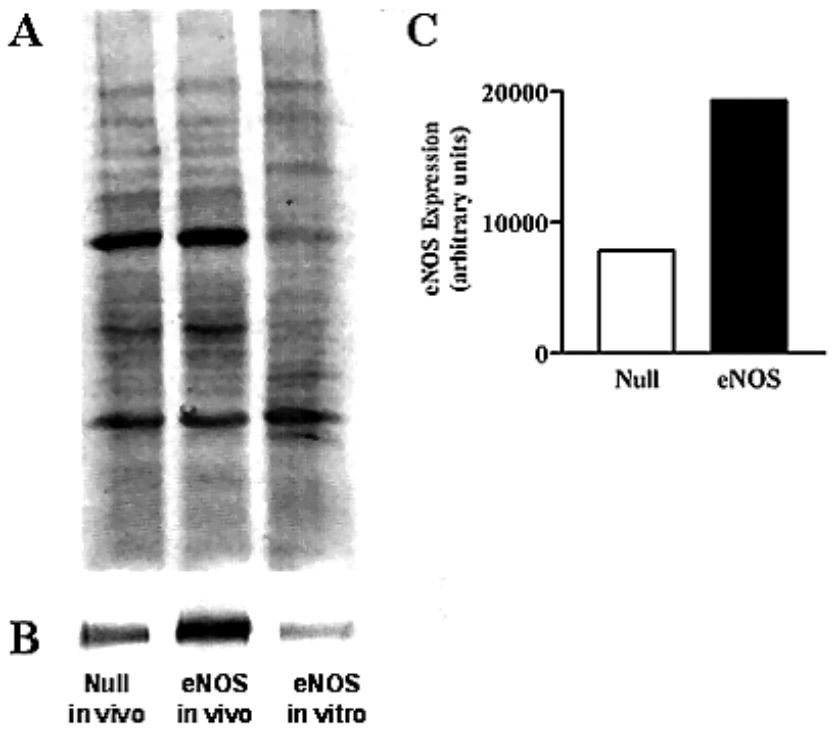

Fig. 2 Western blot analysis of eNOS gene expression in mouse carotids. A Ponceau staining showing equal amounts of loaded protein in each lane. B eNOS signal; left lane: in vivo Ad-Null administration (endogenous eNOS expression); middle lane: in vivo Ad.CMV-eNOS administration; right lane: in vitro positive control consisting of endothelial cells (HUVECs) infected with Ad.CMV-eNOS (not for quantitative comparison). C Quantitative analysis of eNOS proetin levels in $\mathrm{ApoE}^{-/-}$carotids in vivo; Ad-Null (white column), Ad.CMV-eNOS (black column; $n=3$ each)

\section{eNOS gene transfer improves endothelium-dependent relaxations}

In carotid rings transduced with Ad-eNOS in vivo, endothelium-dependent relaxations to acetylcholine were markedly enhanced as compared to those instilled with Ad-Null (Fig. 3, $p<0.01$ ), while the responses to sodium nitroprusside did not show significant differences between the two groups. These data demonstrate that
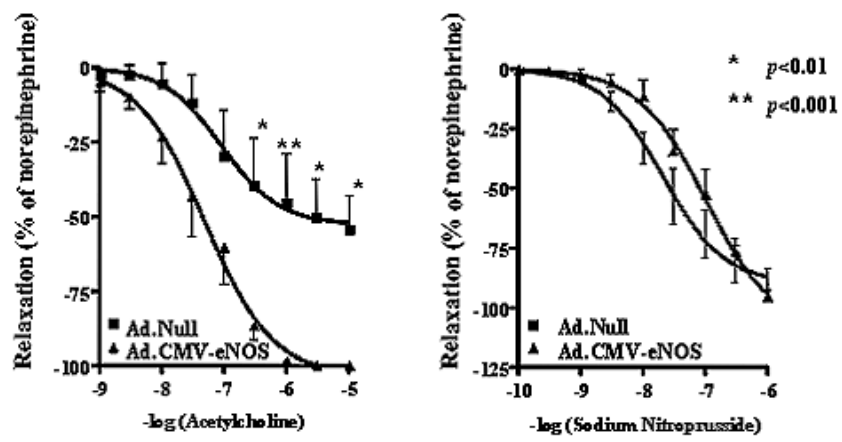

Fig. 3 Endothelium-dependent and -independent relaxation responses to acetylcholine (left) and sodium nitroprusside (right), respectively, in $\mathrm{ApoE}^{--}$carotids infused with Ad.CMV-eNOS (triangles) or Ad-Null (square symbols). Endotheliumdependent relaxation is reduced in control arteries but is improved in eNOS genetransduced arteries

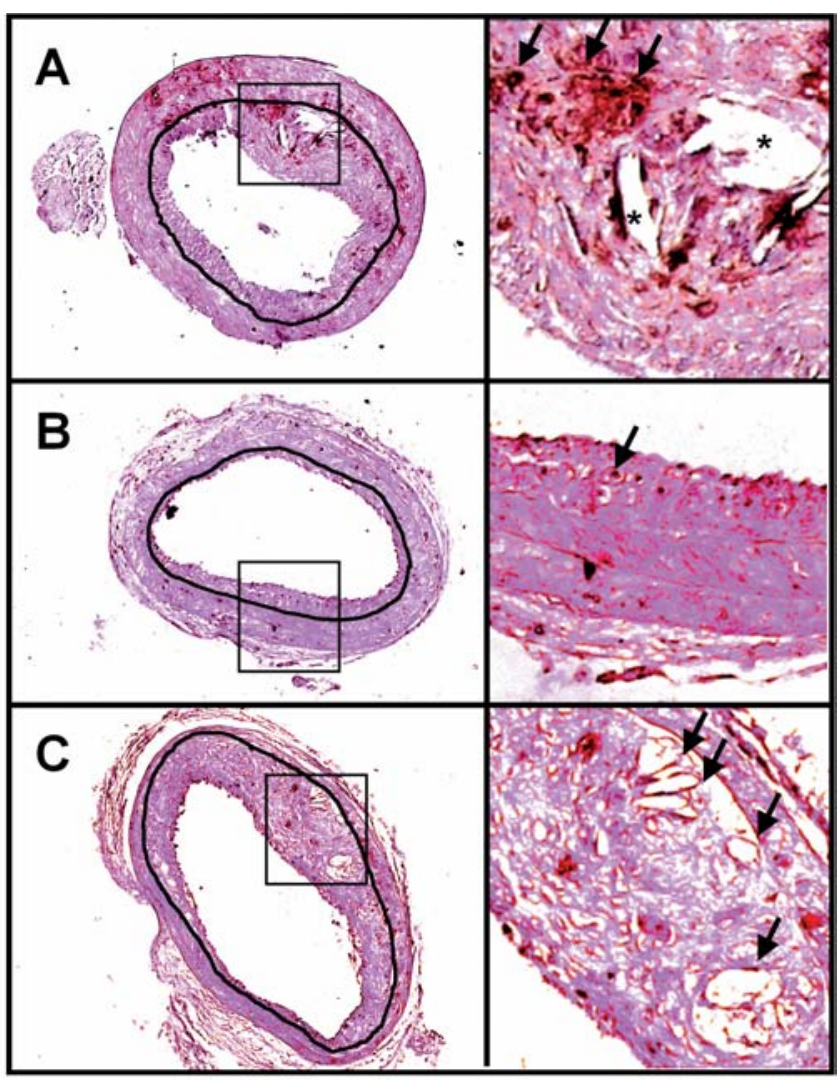

Fig. 4 Representative Mac-2 immunostained cross-sections of $\mathrm{ApoE}^{-/-}$carotids 5 weeks after gene transfer. Right panels are high-magnification fields from left panels. Internal elastic laminae encompassing the lesions are drawn in black for better visualisation; counter-staining with eosin. A Ad-Null; large, macrophage-rich (brown; arrows) lesion containing cholesterol crystal clefts (*). B Ad.CMV-eNOS; smaller lesion with less abundant macrophages (arrow). C Ad.CMV-8ND-MCP-1; large lesion containing abundant foam cells (arrows)

eNOS gene transfer improves endothelium-dependent relaxations in $\mathrm{ApoE}^{-/-}$mouse carotid arteries.

\section{Morphometric analysis of gene-transduced arteries}

Five weeks after gene transfer, arterial lesions had appeared in all experimental groups (Fig. 4). Lesions ranged from small intimal lesions, which were more frequent in the Ad.CMV-eNOS group $(n=6$; one additional mouse died before completion of follow-up; Fig. 4B), to atheromatous plaques rich in foam cells, which were more frequent in the Ad-Null and Ad.CMV-8ND-MCP1 groups ( $\mathrm{n}=7$ each; Fig. $4 \mathrm{~A}$ and $\mathrm{C}$, respectively). Cholesterol crystal clefts were seen occasionally in the last two groups. In the Ad.CMV-eNOS, Ad.CMV-8ND-MCP1 , and Ad-Null groups, intima surface area was 0.031 $(0.002-0.068) \mathrm{mm}^{2}(p<0.05), 0.053(0.015-0.152) \mathrm{mm}^{2}$ (NS), and $0.073(0.013-0.126) \mathrm{mm}^{2}$, respectively; media surface area was $0.058(0.053-0.075) \mathrm{mm}^{2}, 0.053$ 
A

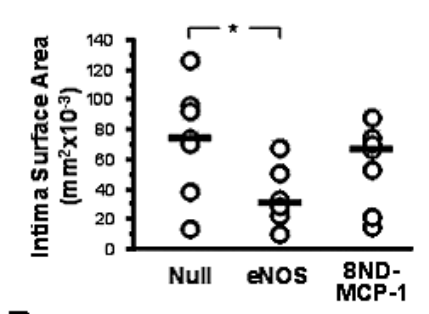

B

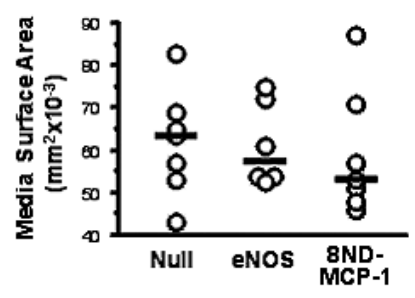

C



eNOS compared with the Ad-Null group: 19 (6-36) vs. 45 $(28-102 ; p<0.01)$, respectively.

\section{Plasma lipid levels}

Differences in plasma total cholesterol and HDL-C among groups were not statistically significant. One week after gene transfer and onset of the Western-type diet, total cholesterol in the Ad.CMV-eNOS, Ad.CMV$8 \mathrm{ND}-\mathrm{MCP}-1$, and Ad-Null groups was $463 \pm 28,418 \pm 34$, and $424 \pm 84 \mathrm{mg} / \mathrm{dl}$, while HDL-C was $64 \pm 9,54 \pm 11$, and $66 \pm 11 \mathrm{mg} / \mathrm{dl}$, respectively. Four weeks after gene transfer, when rats were fed standard chow, total cholesterol in the same groups was $248 \pm 31,323 \pm 26$ and $316 \pm 47$ $\mathrm{mg} / \mathrm{dl}$, while HDL-C was $40 \pm 8,37 \pm 4$, and $51 \pm 3 \mathrm{mg} / \mathrm{dl}$, respectively.

Fig. 5 Quantitative analysis of lesion size in $\mathrm{ApoE}^{-/-}$mouse carotids. A Intima surface area; B Media surface area. CIntima/media ratio. Null, eNOS, and 8ND-MCP-1 refer to arteries instilled with the respective adenoviral vectors. Circles and horizontal bars are individual and median values, respectively. $p$-values for differences between each treatment group and the Ad-Null control group are shown

(0.044-0.089) $\mathrm{mm}^{2}$ (both NS), and $0.065(0.043-0.095)$ $\mathrm{mm}^{2}$; the intima/media ratio was $0.59(0.17-0.95 ; p<$ $0.05), 1.07(0.30-1.80 ; \mathrm{NS})$ and $1.22(0.30-1.87)$, respectively (Fig. 5).

\section{Macrophage content in eNOS gene-transduced arteries}

Macrophage contents in the intima and media normalized by the respective surface areas are shown in Fig. 6 . In the Ad.CMV-eNOS and Ad-Null groups, macrophages in intimal lesions were 54 (2-101) and 146 (26-165; NS), respectively. Macrophages in the media were less abundant than in the intima and decreased in the Ad.CMV-

A

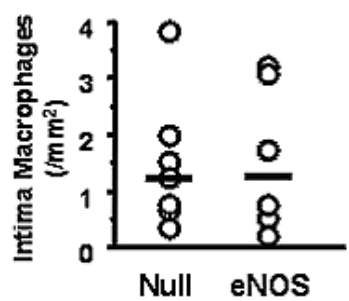

Fig. 6 Quantitative analysis of macrophage densities in $\mathrm{ApoE}^{-/-}$mouse carotids instilled with Ad.CMV-eNOS or Ad-Null. A Intimal lesions. B Tunica media. Macrophages are normalized by the respective surface areas. Circles and horizontal bars are individual and median values, respectively. $p$-values for differences between each treatment group and the Ad-Null control group are shown

\section{Discussion}

Many gene therapy approaches to arteriosclerosis have focused on the systemic delivery of genes that encode proteins involved in lipid metabolism. Alternatively, genes that encode vasoprotective factors have been delivered directly to the vessel wall. Systemic and localized gene transfer approaches are associated with distinct advantages and disadvantages. In analogy to conventional lipid-lowering drugs, systemic gene transfer of a protein involved in lipid metabolism may affect atherosclerotic lesions spread throughout the arterial system. However, systemic gene overexpression may also be associated with systemic side effects, as exemplified by hypotension as a result of systemic eNOS overexpression [28]. Localized gene transfer into targeted vessels aims to protect vessel segments where arteriosclerosis is most likely to develop, or where its complications are most likely to occur. Using this approach, we have evaluated adenovirus-mediated in vivo eNOS and anti-MCP-1 gene therapy in carotid arteries in arteriosclerosis-prone Apo: $\mathrm{E}^{-/}$mice. Experimental and clinical evidence indicates that the balance between eNOS and MCP-1 bioactivities plays an important role in atherogenesis. Endothelial NO activity is decreased at early stages of atherosclerosis, frequently associated with decreased levels of eNOS expression [13, 27, 47]. However, decreased NO bioactivity has been observed also in diseased arteries that show normal or even increased eNOS protein levels $[2,12]$. These findings illustrate the complexity of the relationships between eNOS expression, NO bioactivity, and atherogenesis.

The main findings of the present study are that eNOS gene transfer improves endothelium-dependent relaxations and attenuates lesion formation in carotid arteries in $\mathrm{ApoE}^{-/-}$mice. Studies from other groups showed 
impaired endothelium-dependent vasodilation in carotid arteries in $\mathrm{ApoE}^{-/-}$mice fed a Western-type diet [12]. In the present study, we showed that in vivo eNOS gene transfer into $\mathrm{ApoE}^{-/-}$mouse carotid arteries resulted in increased eNOS expression levels and normalized relaxations to acetylcholine, suggesting exogenous eNOS was functional. To the best of our knowledge, this is the first report showing improved vasodilation by in vivo eNOS gene transfer into $\mathrm{ApoE}^{-/-}$mouse arteries. These results are in general agreement with previous data showing improved endothelium-dependent relaxations by eNOS gene transfer into pulmonary arteries in hypoxic rats [16] and into carotid arteries in hypercholesterolemic rabbits $[8,35]$.

Carotid arteries transduced with the eNOS gene exhibited smaller lesions and lower macrophage contents compared with control arteries. These findings are consistent with previous data showing reduced vascular adhesion molecule expression and decreased inflammatory cell infiltration in eNOS gene-transduced arteries in hypercholesterolemic rabbits $[8,35]$. In addition, several reports showed that eNOS gene transfer can reduce postangioplasty neointima formation in rat, pig and $\mathrm{ApoE}^{-/-}$ mouse arteries [9, 17, 40,45]. However, these models are characterized by mechanical endovascular injury resulting in endothelium denudation, medial cell necrosis, and extensive VSMC proliferation. To the contrary, the model used in the present study is characterized by preserved endothelial integrity, as evidenced by the histologically intact endothelial layer and the observed relaxation responses to acetylcholine after eNOS gene transfer.

eNOS gene transfer may mediate vasoprotection through different biological mechanisms in different vascular disease conditions. NO-mediated inhibition of VSMC proliferation and platelet aggregation may play central roles in reducing neointima formation postangioplasty, while NO-mediated regulation of VSMC differentiation may be important in vascular remodelling of venous bypass grafts $[29,46]$. Regulation of vascular adhesion molecules, of MCP-1 expression, and of vascular inflammation are primary mechanisms by which NO protects vessels in the absence of mechanical endothelial injury $[10,35]$. However, eNOS overexpression may not be invariably beneficial in diseased vessels. It is worth noting that eNOS expression in the endothelium overlying arterial lesions is reduced in the experimental model used in the present study [44]. Moreover, common carotid arteries (unlike the aorta and its branching sites) did not show histological lesions at the time of gene transfer. Under these conditions, eNOS gene transfer may restore, at least in part, eNOS expression in this model. Gene dosage is another important issue. While moderate eNOS overexpression ( $\approx 2.3$-fold increase) was beneficial in the present study, exaggerated eNOS expression might be detrimental due to increased superoxide and peroxynitrite formation, especially in disease conditions that are associated with reduced bioavailability of NO cofactors (e.g., tetrahydrobiopterin) [30, 41]. "Uncoupling" of the NO synthase also involves peroxynitrite oxidation of tetrahydrobiopterin [37]. Our findings of improved endothelium-dependent relaxations in eNOS gene-transduced arteries indicates restored NO bioactivity, thus suggesting that the bioavailability of NO cofactors was not limiting in this model (although this has not been directly measured). It is worth re-emphasizing that our results must be interpreted in the framework to the experimental model used. As such, they are not necessarily applicable to other models or conditions, especially to more advanced stages of the disease.

The second gene construct tested was 8ND-MCP-1. A biological link between MCP-1 and eNOS is supported by observations that NO downregulates MCP-1 expression in endothelial cells, thereby inhibiting monocyte adhesion [26, 37, 38, 49]. Purified 8ND-MCP-1 peptide inhibits with high efficacy MCP-1 binding and signalling through the CCR2 receptor in vitro and MCP-1-mediated monocyte accumulation in inflamed joints in a mouse model of monocyte-rich arthritis in vivo [14]. In the present study, $8 \mathrm{ND}-\mathrm{MCP}-1$ gene transfer did not prevent lesion formation in carotid arteries in $\mathrm{ApoE}^{-/}$mice. Recently, two reports from Takeshita's group showed that systemic gene transfer of 7ND-MCP-1 (which differs from $8 \mathrm{ND}-\mathrm{MCP}-1$ by a single residue) [50] reduces lesion formation and progression in the aortic root in $\mathrm{ApoE}^{-/-}$mice $[15,25]$. A direct comparison of these data with our results is precluded by methodological differences regarding the following aspects: (1) Gene transfer vector (hemaggluting virus of Japan-liposomes vs. adenovirus); (2) MCP-1 inhibitor (7ND vs. $8 \mathrm{ND}$ ); (3) Gene dosage (two doses vs. single dose); (4) Target vessel (aortic root vs. carotid artery); (5) Atherogenic stimuli (Western-type diet vs. surgical manipulation and perivascular collar); and (6) Route of gene administration (systemic vs. arterial gene transfer in the previous and the present study, respectively). In spite of divergent conclusions as to the efficacy of ND-MCP-1 gene therapy in the respective models, however results from the previous [25] and the present study actually are not contradictory. Indeed, mean values for inhibition of lesion surface areas were similar in the two studies $(\approx 30 \%$ and $27 \%$, respectively). However, the decrease in lesion surface area did not reach statistical significance in the present study due to greater data variation. Surgical manipulation of the target vessel and implantation of a perivascular collar presumably contributed to inter-individual variation which appears to be inherent to the model [44]. For comparison of ND-MCP-1 expression, we injected our Ad.CMV-8ND-MCP-1 vector into remote muscles in a separate group of mice according to the protocol used in the two previous studies [15, 25]. Human ND-MCP-1 protein levels determined by ELISA in injected muscles 
at 1 and 4 weeks post-gene transfer (data not shown) were comparable to those reported in the previous study [15], suggesting 8ND-MCP-1 expression levels from our adenoviral vector were adequate. It is conceivable that systemic gene transfer of a secreted ND-MCP-1 peptide may be more effective than direct arterial gene transfer because it blocks the CCR2 receptor on circulating monocytes. From the point of view of potential applications, however, systemic anti-MCP-1 gene therapy raises safety concerns because monocyte/macrophage activities are important mechanisms against infection and cancer.

Limitations of the present study include the short follow-up time ( 5 weeks) and the use of a perivascular collar. Because of the limited duration ( $\approx 2-6$ weeks) of adenovirus-mediated transgene expression in mouse arteries $[18,42]$, it was necessary to stimulate arterial lesion formation within this time frame in order to assess the biological effects of the delivered genes. To achieve this goal, we used a recently described model [44, 45] based on a perivascular collar that acts by inducing flow disturbances that accelerate lesion formation, while maintaining blood flow. This model seemed highly preferable compared to traditional balloon-injury models because it preserves endothelial integrity, as discussed above.

\section{Conclusion}

eNOS gene transfer improved endothelium-dependent relaxations and inhibited lesion formation in carotid arteries in $\mathrm{ApoE}^{-/-}$mice. This is one of the first reports on decreased lesion formation as a result of arterial gene transfer of a protective factor in a primary arteriosclerosis model. A previous report [18] showed that adenovirus-mediated gene transfer of heme oxygenase-1 (HO-1), an enzyme involved in iron metabolism and cytoprotection, inhibits lesion formation in the aorta in ApoE $^{-/}$mice (6-week follow-up). Of note, the same vector was ineffective when delivered systemically, which emphasizes the role of localized gene delivery depending on the therapeutic gene. Gene transfer vectors such as adeno-associated virus (AAV) vectors that provide a potential for prolonged transgene expression in the vessel wall [34] could eventually achieve sustained therapeutic effects in vascular gene therapy. On the other hand, NO donors with a very long half-life could offer an alternate approach to eNOS gene therapy, which may warrant further investigation in preclinical arteriosclerosis models.

Acknowledgments This study was supported by the Swiss National Science Foundation (grant 3100-52600.97), the Teo Rossi di Montelera Foundation and the "Foundation Vaudoise de Cardiologie", Lausanne, Switzerland. The authors wish to thank Sylvain Fleury, $\mathrm{PhD}$, and $\mathrm{Dr}$ Eleonora Simeoni, PhD, Division of Experimental Surgery, and Lucia Mazzolai, MD, Division of Vascular Medicine, Faculty of Biology and Medicine, University of Lausanne, Switzerland, for scientific collaboration, and Monique Bouhans, RA, for technical assistance.

\section{References}

1. Aji W, Ravalli S, Szabolcs M, Jiang XC, Sciacca RR, Michler RE, Cannon PJ (1997) L-arginine prevents xanthoma development and inhibits atherosclerosis in LDL receptor knockout mice. Circulation 95:430-437

2. Bauersachs J, Bouloumi A, Fraccarollo D, Hu K, Busse R, Ertl G (1999) Endothelial dysfunction in chronic myocardial infarction despite increased vascular endothelial nitric oxide synthase and soluble guanylate cyclase expression: role of enhanced vascular superoxide production. Circulation 100:292-298

3. Boger RH, Bode-Boger SM, Brandes RP, Phivthongngam L, Bohme M, Nafe R, Mugge A, Frolich JC (1997) Dietary Larginine reduces the progression of atherosclerosis in cholesterol-fed rabbits: comparison with lovastatin. Circulation 96:1282-1290
4. Boring L, Gosling J, Cleary M, Charo IF (1998) Decreased lesion formation in CCR2 ${ }^{-}$mice reveals a role for chemokines in the initiation of atherosclerosis. Nature 394:894-897

5. Buttery LDK, Chester AH, Springall DR, Borland JAA, Michel T, Yacoub MH, Polar JM (1996) Explanted vein grafts with an intact endothelium demonstrate reduced focal expression of endothelial nitric oxide synthase specific to atherosclerotic sites. J Pathol 179:197-203

6. Cable DG, Pompili VJ, O'Brien T, Schaff HV (1999) Recombinant gene transfer of endothelial nitric oxide synthase augments coronary artery relaxation during hypoxia. Circulation 100 (suppl II): II-335-II-339

7. Cayette AJ, Palacino JJ, Horten K, Cohen RA (1994) Chronic inhibition of nitric oxide production accelerates neointima formation and impairs endothelial function in hypercholesterolemic rabbits. Arterioscler Thromb 14:753-759
8. Channon KM, Qian H, Neplioueva V, Blazing MA, Olmez E, Shetty GA, Youngblood SA, Pawloski J, McMahon T, Stamler JS, George SE (1998) In vivo gene transfer of nitric oxide synthase enhances vasomotor function in carotid arteries from normal and cholesterol-fed rabbits. Circulation 98:1905-1911

9. Channon KM, Qian H, George SE (2000) Nitric oxide synthase in atherosclerosis and vascular injury. Insights from experimental gene therapy. Arterioscler Thromb Vasc Biol 20:1873-1881

10. Cooke JP, Dzau VJ (1997) Nitric oxide synthase: role in the genesis of vascular disease. Annu Rev Med 48:489-509

11. Drexler H, Zeiher AM, Meinzer K, Just $H$ (1991) Correction of endothelial dysfunction in coronary microcirculation of hypercholaesterolemic patients by Larginine. Lancet 338:1546-1550 
12. d'Uscio LV, Smith LA, Katusic ZS (2001) Hypercholesterolemia impairs endothelium-dependent relaxations in common carotid arteries of apolipoprotein E-deficient mice. Stroke 32:2658-2664

13. d'Uscio LV, Milstien S, Richardson D, Smith L, Katusic ZS (2003) Long-term vitamin $C$ treatment increases vascular tetrahydrobiopterin levels and nitric oxide synthase activity. Circ Res 92:88-95

14. Gong J-H, Ratkay LG, Waterfield JD, Clark-Lewis I (1997) An antagonist of monocyte chemoattractant protein 1 (MCP-1) inhibits arthritis in the MRL-lpr mouse model. J Exp Med 186:131-137

15. Inoue S, Egashira K, Ni W, Kitamoto S, Usui M, Otani K, Ishibashi M, Hiasa K, Nishida K, Takeshita A (2002) Antimonocyte chemoattractant protein-1 gene therapy limits progression and destabilization of established atherosclerosis in apolipoprotein E-knockout mice. Circulation 106:2700-2706

16. Janssens S, Bloch KD, Nong Z, Gerard RD, Zoldhelyi P, Collen D (1996) Adenoviralmediated transfer of the human endothelial nitric oxide synthase gene reduces acute hypoxic pulmonary vasoconstriction in rats. J Clin Invest 98:317-324

17. Janssens S, Flaherty D, Nong Z, Varenne O, van Pelt N, Haustermans C, Zoldhelyi P, Gerard R, Collen D (1998) Human endothelial nitric oxide synthase gene transfer inhibits vascular smooth muscle cell proliferation and neointima formation after balloon injury in rats. Circulation 97:1274-1281

18. Juan S-H, Lee T-S, Tseng K-W, Liou J-Y, Shyue S-K, Wu KK, Chau L-Y (2001) Adenovirus-mediated heme oxygenase- 1 gene transfer inhibits the development of atherosclerosis in apolipoprotein E-deficient mice. Circulation 104:1519-1525

19. Kawashima S, Yamashita T, Ozaki M, Ohashi $\mathrm{Y}$, Azumi H, Inoue N, Hirata $\mathrm{K}$, Hayashi Y, Itoh H, Yokoyama M (2001) Endothelial NO synthase overexpression inhibits lesion formation in mouse model of vascular remodeling. Arterioscler Thromb Vasc Biol 21:201-207

20. Kuhlencordt PJ, Gyurko R, Han F, Scherrer-Crosbie M, Aretz TH, Hajjar R, Picard MH, Huang PL (2001) Accelerated atherosclerosis, aortic aneurysm formation, and ischemic heart disease in apolipoprotein E/endothelial nitric oxide synthase double-knockout mice. Circulation 104:448-454

21. Lake-Bruse KD, Faraci FM, Shesely EG, Maeda N, Sigmund CD, Heistad DD (1999) Gene transfer of endothelial nitric oxide synthase in eNOS-deficient mice. Am J Physiol 277 (Heart Circ Physiol 46):H770-H776
22. Lu B, Rutledge BJ, Gu L, Fiorillo J, Lukacs NW, Kunkel SL, North R, Gerard C, Rollins BJ (1998) Abnormalities in monocyte recruitment and cytokine expression in monocyte chemoattractant protein 1-deficient mice. J Exp Med 187:601-608

23. Lund DD, Faraci FM, Miller FJ Jr, Heistad DD (2000) Gene transfer of endothelial nitric oxide synthase improves relaxation of carotid arteries from diabetic rabbits. Circulation 101:1027-1023

24. Ming XF, Viswambharan H, Barandier C, Ruffieux J, Kaibuchi K, Rusconi S, Yang Z (2002) Rho GTPase/Rho kinase negatively regulates endothelial nitric oxide synthase phosphorylation through the inhibition of protein kinase B/Akt in human endothelial cells. Mol Cell Biol 22:8467-8477

25. Ni W, Egashira K, Kitamoto S, Kataoka $\mathrm{C}$, Koyanagi $\mathrm{M}$, Inoue $\mathrm{S}$, Imaizumi $\mathrm{K}$, Akiyama C, Nishida KI, Takeshita A (2001) New anti-monocyte chemoattractant protein-1 gene therapy attenuates atherosclerosis in apolipoprotein E-knockout mice. Circulation 103:2096-2101

26. Niebauer J, Dulak J, Chan JR, Tsao PS, Cooke JP (1999) Gene transfer of endothelial nitric oxide synthase: effects on endothelial biology. J Am Coll Cardiol 34:1201-1207

27. Oemar BS, Tschudi MR, Godoy N, Brovkovich V, Malinski T, Luscher TF (1998) Reduced endothelial nitric oxide synthase expression and production in human atherosclerosis. Circulation 97:2494-2498

28. Ohashi Y, Kawashima S, Hirata K, Yamashita T, Ishida T, Inoue N, Sakoda T, Kurihara H, Yazaki Y, Yokoyama M (1998) Hypotension and reduced nitric oxide-elicited vasorelaxation in transgenic mice overexpressing endothelial nitric oxide synthase. J Clin Invest 102:2061-2071

29. Ohta S, Komori K, Yonemitsu Y, Onahara T, Matsumoto T, Sugimachi K (2002) Intraluminal gene transfer of endothelial cell-nitric oxide synthase suppresses intimal hyperplasia of vein grafts in cholesterol-fed rabbit: A limited biological effect as a result of the loss of medial smooth muscle cells. Surgery 131:644-653

30. Ozaki M, Kawashima S, Yamashita T, Hirase T, Namiki M, Inoue N, Hirata K, Yasui H, Sakurai H, Yoshida Y, Masada M, Yokoyama M (2002) Overexpression of endothelial nitric oxide synthase accelerates atherosclerotic lesion formation in apoE-deficient mice. J Clin Invest 110:331-340

31. Palmer RM, Ashton DS, Moncada S (1988) Vascular endothelial cells synthesize nitric oxide from L-arginine. Nature 333:664-666
32. Parhami F, Fang ZT, Fogelman AM, Andalibi A, Territo MC, Berliner JA (1993) Minimally modified low density lipoprotein-induced inflammatory responses in endothelial cells are mediated by cyclic adenosine monophosphate. J Clin Invest 92:471-478

33. Piedrahita JA, Zhang SH, Hagaman JR, Oliver PM, Maeda N (1992) Generation of mice carrying a mutant apolipoprotein $\mathrm{E}$ gene inactivated by gene targeting in embryonic stem cells. Proc Natl Acad Sci USA 89:4471-4475

34. Post H, Kajstura J, Lei B, Sessa WC, Byrne B, Anversa P, Hintze TH, Recchia FA (2003) Adeno-associated virus mediated gene delivery into coronary microvessels of chronically instrumented dogs. J Appl Physiol 95:1688-1694

35. Qian H, Neplioueva V, Shetty GA, Channon KM, George SE (1999) Nitric oxide synthase gene therapy rapidly reduces adhesion molecule expression and inflammatory cell infiltration in carotid arteries of cholesterol-fed rabbits. Circulation 99:2979-2982

36. Rollins BJ (1996) Monocyte chemoattractant protein 1: a potential regulator of monocyte recruitment in inflammatory disease. Mol Med Today 2:198-204

37. Tomita H, Egashira K, Kubo-Inoue M, Usui M, Koyanagi M, Shimokawa $\mathrm{H}$, Takeya M, Yoshimura T, Takeshita A (1998) Inhibition of NO synthesis induces inflammatory changes and monocyte chemoattractant protein-1 expression in rat hearts and vessels. Arterioscler Thromb Vasc Biol 18:1456-1464

38. Tsao PS, Wang B, Buitrago R, Shyy JY, Cooke JP (1997) Nitric oxide regulates monocyte chemotactic protein-1. Circulation 96:934-940

39. Usui M, Egashira K, Ohtani K, Kataoka C, Ishibashi M, Hiasa K, Katoh M, Zhao Q, Kitamoto S, Takeshita A (2002) Antimonocyte chemoattractant protein-1 gene therapy inhibits restenotic changes (neointimal hyperplasia) after balloon injury in rats and monkeys. FASEB J 16:1838-1840

40. Varenne O, Pislaru S, Gillijns H, Van Pelt N, Gerard RD, Zoldhelyi P, Van de Werf F, Collen D, Janssens SP (1998) Local adenovirus-mediated transfer of human endothelial nitric oxide synthase reduces luminal narrowing after coronary angioplasty in pigs. Circulation 98:919-926

41. Vasquez-Vivar J, Kalyanaraman B, Martasek P, Hogg N, Masters BS, Karoui H, Tordo P, Pritchard KA Jr (1998) Superoxide generation by endothelial nitric oxide synthase: the influence of cofactors. Proc Natl Acad Sci USA 95:9220-9225 
42. Vassalli G, Agah R, Qiao R, Aguilar C, Dichek DA (1999) A mouse model of arterial gene transfer: Antigen-specific immunity is a minor determinant of the early loss of adenovirus-mediated transgene expression. Circ Res 85:e25-e32

43. Verbeuren TJ, Coene MC, Jordaens FH, Van Hove CE, Zonnekeyn LL, Herman A (1986) Effect of hypercholesterolemia on vascular reactivity in the rabbit. II. Influence of treatment with dipyridamole on endothelium-dependent and endothelium-independent responses in isolated aortas of control and hypercholesterolemic rabbits. Circ Res 59:496-504
44. Von der Thüsen JH, van Berkel TJC, Biessen EAL (2001) Induction of rapid atherogenesis by perivascular carotid collar placement in apolipoprotein Edeficient and low-density lipoprotein receptor-deficient mice. Circulation 103:1164-1170

45. Von der Thüsen JH, Fekkes ML, Passier R, van Zonneveld, Mainfroid V, van Berkel TJC, Biessen EAL (2004) Adenoviral transfer of endothelial nitric oxide synthase attenuates lesion formation in a novel murine model of postangioplasty restenosis. Arterioscler Thromb Vasc Biol 24:357-362

46. West NE, Qian H, Guzik TJ, Black E, Cai S, George SE, Channon KM (2001) Nitric oxide synthase (nNOS) gene transfer modifies venous bypass graft remodeling: effects on vascular smooth muscle cell differentiation and superoxide production. Circulation 104:1526-1532

47. Wilcox JN, Subramanian RR, Sundell CL, Tracey WR, Pollock JS, Harrison DJ, Marsden PA (1997) Expression of multiple isoforms of nitric oxide synthase in normal and atherosclerotic vessels. Arterioscler Thromb Vasc Biol 17:2479-2488
48. Yla-Herttuala S, Lipton BA, Rosenfeld ME, Sarkioja T, Yoshimura T, Leonard EJ, Witztum JL, Steinberg D (1991) Expression of monocyte chemoattractant protein 1 in macrophage-rich areas of human and rabbit atherosclerotic lesions. Proc Natl Acad Sci USA 88:5252-5256

49. Zeiher AM, Fisslthalter B, Schray-Utz B, Busse R (1995) Nitric oxide modulates the expression of monocyte chemoattractant protein 1 in cultured human endothelial cells. Circ Res 76:980-986

50. Zhang YJ, Rutledge BJ, Rollins BJ (1995) A dominant negative inhibitor indicates that monocyte chemoattractant protein 1 functions as a dimer. Mol Cell Biol 15:4851-4855

51. Zong P, Tune JD, Setty S, Downey HF (2002) Endogenous nitric oxide regulates right coronary blood flow during acute pulmonary hypertension in conscious dogs. Basic Res Cardiol 97:392-398 